\title{
A Possible Role for the Adenylcyclase System in Insulin Secretion*
}

\author{
W. J. Malaisse, $\$$ F. Malaisse-Lagae, and D. Mayhew \\ (From the Department of Pharmacology, Indiana University School of Medicine, \\ Indianapolis, Indiana)
}

\begin{abstract}
A possible role for adenylcyclase in insulin secretion was investigated. Isoproterenol, a predominantly $\beta$-adrenergic agent, when mixed with an $\alpha$-adrenergic blocking agent (phenoxybenzamine), stimulated insulin secretion from pieces of the rat's pancreas in vitro. Theophylline, caffeine, 3'5'-cyclic AMP, glucagon, adrenocorticotropin (ACTH), and thyrotropin (TSH), all of which are thought to act through the adenylcyclase systems in the liver and adipose tissue, also stimulated insulin secretion in vitro; oxytocin and vasopressin, which do not stimulate lipolysis in adipose tissue, were inactive. In all cases, stimulation of insulin secretion could not be detected when glucose was absent or present in only low concentrations (less than $100 \mathrm{mg} / 100 \mathrm{ml})$ and was maximal at high levels of glucose $(300 \mathrm{mg} / 100 \mathrm{ml})$. When pancreatic tissue was obtained from normoglycemic rats and contained no detectable glycogen in the Islets, the stimulant effects of glucose and of theophylline were reduced or abolished by mannoheptulose and 2-deoxyglucose. When tissue was derived from rats infused for 8-10 hr with glucose and contained glycogen, theophylline, even in the absence of glucose, stimulated secretion and this effect was reduced by 2-deoxyglucose but not by mannoheptulose. It is suggested that the $\beta$-cell contains an adenylcyclase system through which phosphorylase and possibly phosphofructokinase could be activated; and that insulin secretion could depend upon and be regulated by hormones and other substances which influence the rate at which glycolysis proceeds within the $\beta$-cell.
\end{abstract}

\section{Introduction}

In 1964, Coore and Randle reported inhibition by epinephrine of the stimulant effect of glucose on insulin output from the rabbit's pancreas (1); this observation has since been confirmed in experiments carried out in vivo (2-4) and in vitro (5). More recently, we have suggested that the inhibitory effects of catecholamines are mediated

* Received for publication 20 February 1967 and in revised form 10 July 1967.

This work was supported by grant PHS-AM-7211-02 from the U. S. Public Health Service.

$¥$ This work was performed during the tenure of an International postdoctoral research fellowship of the U. S. Public Health Service, 2 FO 5-TW-865-02.

Address requests for reprints to Dr. W. J. Malaisse, The Department of Pharmacology, Indiana University School of Medicine, Indianapolis, Ind. 46207. through activation of $\alpha$-adrenergic receptors; they are entirely blocked by $\alpha$-, but little affected by $\beta$-adrenergic blocking agents (5). These observations led us to investigate the possible role of the adenylcyclase system in the control of insulin secretion. Using a simple method for the measurement of insulin secretion by the rat's pancreas in vitro (6), we studied the effects upon insulin secretion of (a) substances known to activate $\beta$-adrenergic receptors; $(b)$ drugs such as $3^{\prime} 5^{\prime}$ cyclic AMP and the methylxanthines which are known to mediate or simulate the activation of the adenylcyclase system (7); and (c) hormones such as glucagon, corticotropin, and thyrotropin, which are thought to activate adenylcyclase in other tissues (8). 


\section{Methods}

Rats. Male albino rats (250-350 g; Holtzman, Wis.) were fed on a standard diet (Lab Chow, Ralston Purina Co., St. Louis, Mo.) until killed by decapitation. Into 11 rats, a hypertonic solution of glucose $(50 \%, \mathrm{w} / \mathrm{v}$; injection dextrose, Eli Lilly \& Co., Indianapolis, Ind.) was administered intravenously at a constant rate $(4.76 \pm$ $0.08 \mathrm{~g}$ of glucose $/ \mathrm{kg}$ of body weight per hr) for $8-10 \mathrm{hr}$ before death. During this period, the animals were fully conscious, had free access to water, and showed marked glycosuria (urinary output $=1.45 \pm 0.11 \mathrm{~g}$ of glucose $/ \mathrm{kg}$ of body weight per $\mathrm{hr}$ ). At death they had very high concentrations of plasma sugar $(1.3 \pm 0.2 \mathrm{~g} / 100 \mathrm{ml})$.

Experimental procedure. After decapitation of the rat, the pancreas was removed, placed in a buffer cooled with ice, and dissected free of lymph nodes and adipose tisste. Small pieces of pancreatic tissue (about $10 \mathrm{mg}$ each) were placed in groups of four into flasks containing $2.0 \mathrm{ml}$ of the incubation medium. All flasks were equilibrated against a mixture of oxygen (95\%) and carbon dioxide (5\%) and then incubated for $60 \mathrm{~min}$ at $36^{\circ} \mathrm{C}$. After incubation, the pieces of tissue were quickly removed from the flasks and weighed. In addition to flasks containing the incubated tissues, control flasks were incubated in the absence of tissue and contained duplicate samples of each of the media studied in that individual experiment.

Incubation media. Pieces of pancreatic tissue were incubated in a bicarbonate-buffered medium (6) containing glucose $(0,50,100,150$, or $300 \mathrm{mg} / 100 \mathrm{ml})$, bovine serum albumin $(0.5 \%, \mathrm{w} / \mathrm{v}$; bovine albumin, Fraction $\mathrm{V}$, Sigma Chemical Co., St. Louis, Mo.), and guinea pig antiinsulin serum (GPAIS, Lot 270) obtained by a method described elsewhere (9). Sufficient GPAIS was added to the medium to bind about twice the expected amount of secreted hormone; the reason for the selection of this concentration is discussed elsewhere (10). Also added to the media, as required, were isoproterenol $(0.001$ mmole/liter; DL- $N$-Isopropylarterenol $\cdot \mathrm{HCl}$, Calbiochem, Los Angeles, Calif.); phenyoxybenzamine (1.0 mmole/ liter; Dibenzyline, Smith, Kline \& French Laboratories, Philadelphia, $\mathrm{Pa}$.) ; adenosine-3'5'-cyclic monophosphoric acid (0.1-7.6 mmoles/liter; Sigma Chemical Co., St. Louis, Mo.); theophylline (0.3-1.4 mmoles/liter); caffeine (1.3 mmoles/liter); nicotinic acid (1.0-20.0 mmoles/liter); propanolol or nethalide (1.0-2.0 mmoles/liter; Inderal or Alderlin, Ayerst Laboratories, New York, N. Y.); phentolamine (1.0 mmole/liter; Regitine, Ciba Pharmaceutical Co., Summit, N. J.) ; glucagon ( $5 \mu \mathrm{g} / \mathrm{ml}$; beefpork crystalline glucagon, Lot No. 258-234B-167-1, Eli Lilly \& Co., Indianapolis, Ind.) ; corticotropin (1.25 IU/ $\mathrm{ml}$; Acthar) or thyrotropin ( $0.5 \mathrm{IU} / \mathrm{ml}$; Thytropar) from Armour Pharmaceutical Co. (Kankakee, IIl.); oxytocin ( $0.90 \mathrm{IU} / \mathrm{ml}$; Synthetic Oxytocin) donated by Dr. J. H. Trapold, Sandoz, Inc., Hanover, N. J.; pitressin (0.01 $\mathrm{mg} / \mathrm{ml}$; hog-beef pitressin powder RX 301946, which assays 50 pressor U/mg) supplied by Dr. E. D. Nicolaides, Parke, Davis \& Co., Ann Arbor, Mich.; kallikrein inhibitor $(625 \mathrm{KIU} / \mathrm{ml}$; Trasylol, Bayer) from Dr. R. Goesswald, FBA Medical Research, New York, N. Y.; 2-deoxy-

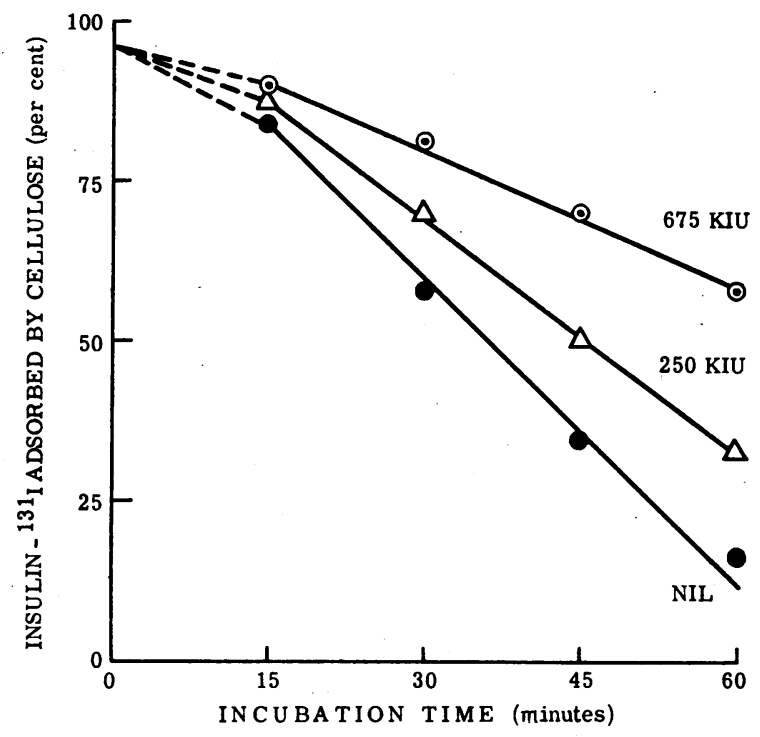

Fig. 1. MEAN PERCENTAGe OF INITIALIy ADDED 19iLABELED INSULIN ADSORBED BY CELLULOSE AFTER INCUBATION FOR PERIODS UP TO 60 MIN OF RAT'S PANCREATIC TISSUE (CA. 400 MG) IN MEDIA (20 ML) CONTAINING LABELED ( $6 \mathrm{MU}$ ) AND UNLABELED (50 MU) BOVINE INSULIN AND VARIOUS CONCENTRATIONS OF KALLIKREIN INHIBITOR $(0,250$, AND $625 \mathrm{KIU} / \mathrm{ML})$. For reasons given elsewhere (13), radioactivity not adsorbed by cellulose is assumed to represent denatured or damaged insulin. Each point represents the mean of two observations.

D-glucose $(150-1330 \mathrm{mg} / 100 \mathrm{ml}$; Aldrich Chemical Co., Inc., Milwaukee, Wis.) and mannoheptulose. Mannoheptulose was contained in a syrup extracted from avocados by the method of Richtmyer (11). It contained no glucose but reducing substances equivalent to glucose in a concentration of $0.7-0.8 \mathrm{~g} / \mathrm{ml}$, and was added to the medium in a final concentration of $0.5 \%(\mathrm{v} / \mathrm{v})$. Kallikrein inhibitor was added to all media containing polypeptidic hormones in order to protect these hormones from the action of lytic substances released into the medium by the acinar tissue (12). Preliminary experiments had shown that kallikrein inhibitor markedly reduces the rate of destruction of insulin by incubated pancreatic tissue (Fig. 1); this protective effect was also observed with other hormones (see Results). When high concentrations of glucose or other drugs were present, isoosmolarity was maintained by reducing the concentration of sodium chloride. When nicotinic acid was added in high concentration (20.0 mmoles/liter), normal pH (7.4) was restored by addition of sodium bicarbonate. Finally, commercial preparations of oxytocin and lysine8-vasopressine containing chlorobutanol were not used since this preservative causes marked inhibition of insulin secretion even in a concentration of $0.25 \mathrm{mg} / \mathrm{ml}$.

Measurement of insulin secretion. Secreted insulin was equated with the fall in insulin antibody content of the medium during incubation. Full details of the method for assay of the insulin-antibody are described 
elsewhere (13). Insulin secretion rates are expressed as microunits of insulin secreted per milligram of incubated tissue per $60 \mathrm{~min}$. In one or more experiments, insulin secretion was measured in equal numbers of flasks $(n)$ containing glucose alone, and glucose with the added drug. Mean differences $(\mathrm{df}=2 n-2)$ in secretion rates found under these conditions are here quoted together with the mean absolute rates of secretion ( \pm SEM) obtained in all experiments where only glucose was present in the medium.
None of the drugs listed above, including glucagon, reacted to any detectable degree with the antibody in GPAIS. Thyrotropin $(0.5 \mathrm{IU} / \mathrm{ml})$ prevented the absorption by cellulose of a small fraction (4-5\%) of the ${ }^{131} \mathrm{I}$-labeled insulin used in the assay procedure. However, unlabeled insulin $(2.0 \mathrm{mU} / \mathrm{ml})$ preincubated $\left(36^{\circ} \mathrm{C}\right.$, $30 \mathrm{~min})$ with thyrotropin $(0.5 \mathrm{IU} / \mathrm{ml})$ retained its full ability to neutralize GPAIS (unpublished observations). This fact was taken into account when secretion rates were calculated under this experimental condition.

TABLE I

Changes in insulin secretion produced by isoproterenol, 3'5'-cyclic AMP, methylxanthines, nicotinic acid, and adrenergic blocking agents.

\begin{tabular}{|c|c|c|c|c|c|c|c|}
\hline & \multirow{2}{*}{$\begin{array}{l}\text { Line } \\
\text { No. }\end{array}$} & \multirow{2}{*}{$\underset{\text { (mmoles/liter) }}{\operatorname{Drug}}$} & \multicolumn{5}{|c|}{ Glucose concentration $(\mathrm{mg} / 100 \mathrm{ml})$} \\
\hline & & & 0 & 50 & 100 & 150 & 300 \\
\hline (i) & 1 & $\mathrm{Nil}$ & $\begin{array}{r}10.2 \pm 1.9 \\
(27)\end{array}$ & $\begin{array}{r}12.4 \pm 3.6 \\
(9)\end{array}$ & $\begin{array}{r}11.6 \pm 1.3 \\
(50)\end{array}$ & $26.8 \pm 1.3$ & $\begin{array}{r}59.0 \pm 2.7 \\
(54)\end{array}$ \\
\hline \multirow[t]{15}{*}{ (ii) } & 2 & Isoproterenol $(0.001)$ & & & & $-10.2 \pm 3.2^{*}$ & $\begin{array}{c}-23.8 \pm 7.6 \ddagger \\
(9)\end{array}$ \\
\hline & 3 & $\begin{array}{l}\text { Isoproterenol }(0.001) \\
\quad+\text { phenoxybenzamine }(1.0)\end{array}$ & $+4.9 \pm \underset{(9)}{2.18}$ & & $+6.8 \pm \underset{(9)}{2.1 \ddagger}$ & $+7.8 \pm 3.0 \ddagger$ & $+14.4 \pm 5.2 \ddagger$ \\
\hline & 4 & Phenoxybenzamine (1.0) & & & & $-0.1 \pm 5.6$ & \\
\hline & 5 & $3^{\prime} 5^{\prime}$-cyclic AMP (0.1) & & & $-0.1 \pm 5.4$ & & \\
\hline & 6 & $3^{\prime} 5^{\prime}$-cyclic AMP (7.6) & $+1.3 \pm 5.2$ & & $+8.7 \pm 2.5^{*}$ & $+6.4 \pm 2.8 \S$ & $+38.7 \pm \frac{18.2 \S}{(9)}$ \\
\hline & 7 & Theophylline (0.3) & & & & $+17.9 \pm 5.3^{*}$ & \\
\hline & 8 & Theophylline (1.4) & $-2.6 \pm 6.0$ & $+0.9 \pm 5.1$ & $+11.1 \pm 2.3^{*}$ & $\begin{array}{r}+48.7 \pm 3.2^{*} \\
(90)\end{array}$ & $+57.7 \pm 8.5^{*}$ \\
\hline & 9 & Caffeine (1.3) & & & $+11.3 \pm 1.7^{*}$ & $\begin{array}{r}+27.3 \pm 5.5^{*} \\
(18)\end{array}$ & $+\underset{(9)}{47.5 \pm 15.7 \ddagger}$ \\
\hline & 10 & $\begin{array}{l}\left.3^{\prime} 5^{\prime} \text {-cyclic AMP ( } 7.6\right) \\
\text { +theophylline (1.4) }\end{array}$ & & & $\begin{array}{c}+37.2 \pm 4.6^{*} \\
(9)\end{array}$ & $\begin{array}{c}+52.5 \pm 9.2^{*} \\
(9)\end{array}$ & \\
\hline & 11 & $\begin{array}{l}\text { Theophylline }(1.4) \\
\quad+\text { nicotinic acid }(1.0)\end{array}$ & & & & $+43.10 .6^{*}$ & \\
\hline & 12 & $\begin{array}{l}\text { Theophylline }(1.4) \\
\text { + nicotinic acid }(20.0)\end{array}$ & & & & $\begin{array}{r}+50.2 \pm 5.5^{*} \\
(18)\end{array}$ & \\
\hline & 13 & Nicotinic acid (1.0) & & & & $\begin{array}{r}+1.3 \pm 5.9 \\
(9)\end{array}$ & \\
\hline & 14 & Nicotinic acid (20.0) & & & & $+1.9 \pm 3.0$ & \\
\hline & 15 & $\begin{array}{l}\text { Theophylline (1.4) } \\
\text { +propanolol (1.0) }\end{array}$ & & & & $\begin{array}{r}+23.3 \pm 4.8^{*} \\
(36)\end{array}$ & \\
\hline & 16 & Propanolol (1.0) & & & & $-1.9 \pm 3.2$ & \\
\hline
\end{tabular}

(i) Mean insulin secretion ( $\mu \mathrm{U} / \mathrm{mg}$ per $60 \mathrm{~min} \pm \mathrm{SEM}$ ) by tissue incubated in media containing glucose alone; number of observations shown in parentheses.

(ii) Effects of drugs (concentrations shown in parentheses) are shown as mean changes $(+$ or -$)$ in insulin secretion rates $(\mu \mathrm{U} / \mathrm{mg}$ per $60 \mathrm{~min} \pm \mathrm{SEM})$ with their stastistical significance $\left({ }^{*} P<0.005 ; \ddagger P<0.02 ; \S P<0.05\right)$; the number of observations is in parentheses. 


\section{Results}

Effects of isoproterenol, 3'5'-cyclic AMP, and methylxanthines. As shown in Table I (line 1), little insulin was secreted at glucose concentrations of less than $100 \mathrm{mg} / 100 \mathrm{ml}(10-12 \mu \mathrm{U} / \mathrm{mg}$ per 60 $\mathrm{min}$ ) but the rate of secretion rose as the concentration of glucose was increased to $300 \mathrm{mg} / 100 \mathrm{ml}$ (59 $\mu \mathrm{U} / \mathrm{mg}$ per $60 \mathrm{~min}$ ). It was previously shown (5) that this stimulant effect of glucose is inhibited by adrenergic agents such as epinephrine and norepinephrine which are potent activators of the $\alpha$-receptor (14). Insulin secretion induced by glucose $(150 \mathrm{mg} / 100 \mathrm{ml})$ was also reduced by isoproterenol (1 mmole/liter), a predominantly $\beta$-adrenergic agent, from 26.5 to $16.3 \mu \mathrm{U} / \mathrm{mg}$ per $60 \mathrm{~min}$ (net inhibitory effect, $-10.2 \mu \mathrm{U} / \mathrm{mg}$ per $60 \mathrm{~min}$; Table I, line 2). Isoproterenol, however, is not a pure $\beta$-adrenergic agent (14) and when its $\alpha$-adrenergic action was blocked by an $\alpha$-adrenergic blocking drug, phenoxybenzamine, the insulin secretion induced by glucose was slightly increased from 26.8 to $34.6 \mu \mathrm{U} / \mathrm{mg}$ per 60 min (net stimulant effect $+7.8 \mu \mathrm{U} / \mathrm{mg}$ per $60 \mathrm{~min}$; Table I, line 3 ). This slight stimulant effect was not produced by phenoxybenzamine itself (Table I, line 4). It was therefore concluded that activation of the $\beta$-adrenergic receptor by isoproterenol could be responsible for the stimulant effect observed when both isoproterenol and phenoxybenzamine were present in the medium. As the glucose content of the medium was raised (Table I, line 3 ), the stimulant effect of this combination of drugs increased to become most apparent at a glucose concentration of $300 \mathrm{mg} / 100 \mathrm{ml}(+14.4 \mu \mathrm{U} /$ $\mathrm{mg}$ per $60 \mathrm{~min}$ ).

Comparable effects were obtained when cyclic AMP was added to the medium (Table I, lines 5 and 6). Probably due to the low permeability of cellular membranes to this substance (8), low concentrations ( $0.1 \mathrm{mmole} / \mathrm{liter}$ ) of cyclic AMP had no effect upon insulin secretion (Table I, line 5 ); but at high concentrations ( 7.6 mmoles/liter) it increased insulin secretion in proportion to the glucose content of the medium. In the absence of glucose, cyclic AMP at the higher concentration had no detectable effect, its optimal action being found when glucose was present in a concentration of $300 \mathrm{mg} / 100 \mathrm{ml}$ (Table I, line 6). More pronounced effects were obtained with theophylline (Table I, lines 7 and 8), and again no stimulation was observed when glucose was either absent or present in only low concentrations (less than 100 $\mathrm{mg} / 100 \mathrm{ml}$ ). As shown in Table I (line 8), insulin secretion at the three higher glucose concentrations $(100,150$, and $300 \mathrm{mg} / 100 \mathrm{ml})$ was at least doubled by addition of theophylline to the medium, the maximum absolute rate obtained at the highest glucose concentration (about $2.0 \mu \mathrm{U}$ / $\mathrm{mg}$ per min) being greater than that $(1.4 \mu \mathrm{U} / \mathrm{mg}$ per min) observed previously (6) when pancreatic tissue was maximally stimulated by glucose alone in concentrations of $500-750 \mathrm{mg} / 100 \mathrm{ml}$. Almost identical stimulant effects were obtained at the higher concentrations of glucose when caffeine was added to the medium (Table I, line 9) in approximately the same concentration (1.3 mmoles/liter).

As shown in Table I (line 10), when cyclic AMP and theophylline were added to a medium containing glucose in a concentration of $100 \mathrm{mg} /$ $100 \mathrm{ml}$, the stimulant effect of this combination $(+37.2 \pm 4.6 \mu \mathrm{U} / \mathrm{mg}$ per $60 \mathrm{~min})$ was significantly greater $(P<0.005)$ than the sum of the stimulant effects of the two drugs incubated separately $(19.8 \pm 3.4 \mu \mathrm{U} / \mathrm{mg}$ per $60 \mathrm{~min})$. This potentiating effect was not observed at a higher glucose concentration $(150 \mathrm{mg} / 100 \mathrm{ml})$.

The stimulant effect of theophylline was not affected by simultaneous addition of nicotinic acid, even in high concentrations (20.0 mmoles/liter) and nicotinic acid itself had no effect upon the action of glucose (Table I, lines 11-14). In the presence of propanolol, a $\beta$-adrenergic blocking agent, theophylline still increased, though less markedly, the rate of insulin secretion (Table I, line 15); again, propanolol did not modify the stimulant effect of glucose alone (Table I, line 16).

Effect of glucagon. Kallikrein inhibitor inhibits the breakdown of insulin added to incubation media containing pancreatic tissue but no GPAIS (Fig. 1). When added to media containing GPAIS, it had no significant effect upon the action of glucose on insulin secretion (Table IIA, lines 1 and $3)$. These observations suggest, as indicated previously (6), that insulin secreted from the Islets is rapidly bound by the antibodies, before lysis of the hormone can occur. In the absence of kallikrein inhibitor, glucagon failed to increase insulin output (Table IIA, line 2), whereas in its presence a marked increase in secretion was provoked (Table IIA, line 4). Thus kallikrein inhibitor 
TABLE II

Effects of kallikrein inhibitor, nicotinic acid, and adrenergic blocking agents upon insulin secretion stimulated by glucagon

\begin{tabular}{|c|c|c|c|c|c|c|c|c|}
\hline & & \multirow{2}{*}{$\begin{array}{l}\text { Line } \\
\text { No. }\end{array}$} & \multirow{2}{*}{$\underset{\text { (iii) }}{\text { Drug }}$} & \multicolumn{5}{|c|}{ Glucose concentration $(\mathrm{mg} / 100 \mathrm{ml})$} \\
\hline & & & & 0 & 50 & 100 & 150 & 300 \\
\hline \multirow[t]{4}{*}{ A } & (i) & 1 & Nil & & & & $19.7 \pm 3.2$ & $\begin{array}{r}45.2 \pm 4.6 \\
(9)\end{array}$ \\
\hline & (ii) & 2 & Glucagon (G) & & & & $+8.9 \pm 4.6$ & \\
\hline & & 3 & Kallikrein inhibitor $(\mathrm{K})$ & & & & $+5.1 \pm 3.6$ & $-0.4 \pm 6.8$ \\
\hline & & 4 & $\mathrm{~K}+\mathrm{G}$ & & & & $+31.2 \pm 5.5^{*}$ & \\
\hline \multirow[t]{8}{*}{ B } & (i) & 5 & $\mathrm{~K}$ & $\begin{array}{r}8.0 \pm 3.6 \\
(9)\end{array}$ & $\begin{array}{r}6.6 \pm 1.4 \\
(18)\end{array}$ & $\begin{array}{r}11.3 \pm 2.5 \\
(18)\end{array}$ & $27.6 \pm 0.9$ & $\begin{array}{r}53.8 \pm 6.3 \\
(18)\end{array}$ \\
\hline & (ii) & 6 & $\mathrm{~K}+\mathrm{G}$ & $\begin{array}{r}+3.1 \pm 4.4 \\
(9)\end{array}$ & $+0.6 \pm 2.0$ & $+0.7 \pm 2.4$ & $+15.0 \pm \frac{1.8^{*}}{(95)}$ & $\begin{array}{r}+35.9 \pm 8.2^{*} \\
(18)\end{array}$ \\
\hline & & 7 & $\mathrm{~K}+\mathrm{G}+$ nicotinic acid $(20.0)$ & & & & $\begin{array}{r}+22.0 \pm 4.2^{*} \\
(18)\end{array}$ & \\
\hline & & 8 & $\mathrm{~K}+\mathrm{G}+$ phentolamine $(1.0)$ & & & & $\begin{array}{c}+38.3 \pm 6.3^{*} \\
(9)\end{array}$ & \\
\hline & & 9 & $\mathrm{~K}+\mathrm{G}+$ propanolol $(1.0)$ & & & & $+10.3 \pm 4.4 \ddagger$ & \\
\hline & & 10 & $\mathrm{~K}+\mathrm{G}+$ propanolol $(2.0)$ & & & & $\begin{array}{r}+33.0 \pm 5.3^{*} \\
(28)\end{array}$ & \\
\hline & & 11 & $\mathrm{~K}+\mathrm{G}+$ nethalide $(1.0)$ & & & & $\begin{array}{r}+10.2 \pm 3.4^{*} \\
(18)\end{array}$ & \\
\hline & & 12 & $\mathrm{~K}+\mathrm{G}+$ nethalide $(2.0)$ & 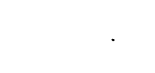 & & & $\begin{array}{r}+21.6 \pm 7.5^{*} \\
(18)\end{array}$ & \\
\hline
\end{tabular}

(i) Mean basal rates of secretion $(\mu \mathrm{U} / \mathrm{mg}$ per $60 \mathrm{~min} \pm \mathrm{SEM})$ by tissue incubated in media containing glucose alone (A), or glucose and kallikrein inhibitor (B); number of observations shown in parentheses.

(ii) Effects upon basal secretion rates produced by added drugs and quoted as mean changes $(+$ or - ) in rate of secretion $(\mu \mathrm{U} / \mathrm{mg}$ per $60 \mathrm{~min} \pm \mathrm{SEM})$ with their statistical significances $\left({ }^{*} P<0.005 ; \ddagger P<0.02\right)$; the number of observations is in parentheses.

(iii) Concentration of added drugs, with the exception of glucagon $(\mathrm{G}, 5 \mu \mathrm{g} / \mathrm{ml})$ and kallikrein inhibitor $(\mathrm{K}, 625$ $\mathrm{KIU} / \mathrm{ml}$ ), are shown in parentheses (mmoles/liter).

seems to protect not only insulin but also other polypeptidic hormones such as glucagon, from the lytic factor released by the acinar tissue (12). In view of these findings, all further experiments involving polypeptidic hormones were carried out in the presence of kallikrein inhibitor which was added both to the media containing hormone and to the control media containing glucose alone.

Increased secretion induced by glucagon $(5 \mu \mathrm{g} /$ $\mathrm{ml}$ ) was not observed at glucose concentrations ranging from 0 to $100 \mathrm{mg} / 100 \mathrm{ml}$. It only became apparent at a glucose concentration of $150 \mathrm{mg} / 100 \mathrm{ml}$ and was further enhanced by raising it to $300 \mathrm{mg} / 100 \mathrm{ml}$ (Table IIB, line 6). The stimulant effect of glucagon persisted despite ad- dition to the medium of nicotinic acid (20.0 mmoles/liter) and $\alpha$-(phentolamine, $1.0 \mathrm{mmole} /$ liter) or $\beta$-(propanolol and nethalide, 1.0-2.0 mmoles/liter) adrenergic blocking agents (Table IIB, lines 7-12). Though somewhat variable results were obtained in these experiments, barely significant differences were only occasionally noticed when the increase in secretion observed with glucagon alone was compared to that observed in the same experiment after simultaneous addition of glucagon and one of its potential antagonists. For instance, there was a tendency for the $\beta$-adrenergic blocking agents $(1.0 \mathrm{mmole} / \mathrm{liter})$ to reduce glucagon-induced secretion (Table IIB, lines 9 and 11), a fact comparable to the reduction 
TABLE III

Changes in insulin secretion produced by corticotropin, thyrotropin, oxytocin, and pitressin

\begin{tabular}{|c|c|c|c|c|c|}
\hline & \multirow{2}{*}{$\begin{array}{l}\text { Line } \\
\text { No. }\end{array}$} & \multirow{2}{*}{$\begin{array}{l}\text { Hormone } \\
(\mathrm{IU} / \mathrm{ml})\end{array}$} & \multicolumn{3}{|c|}{ Glucose concentration $(\mathrm{mg} / 100 \mathrm{ml})$ (iii) } \\
\hline & & & 100 & 150 & 300 \\
\hline (i) & 1 & Nil & $\begin{array}{r}6.9 \pm 2.7 \\
(9)\end{array}$ & $31.7 \pm 2.8$ & $\begin{array}{r}55.6 \pm 4.0 \\
(73)\end{array}$ \\
\hline \multirow[t]{4}{*}{ (ii) } & 2 & Corticotropin (1.2) & $\begin{array}{r}-1.9 \pm 3.2 \\
(9)\end{array}$ & $\begin{array}{r}+7.1 \pm 7.1 \\
(9)\end{array}$ & $\begin{array}{r}+28.9 \pm 8.7^{*} \\
(18)\end{array}$ \\
\hline & 3 & Thyrotropin $(0.5)$ & & $+8.4 \pm 5.7$ & $+19.2 \pm 6.0^{*}$ \\
\hline & 4 & Oxytocin $(0.9)$ & & $+1.8 \pm 6.3$ & $+7.2 \pm 5.7$ \\
\hline & 5 & Pitressin $(0.5)$ & & $+6.3 \pm 6.7$ & $\begin{array}{r}0.1 \pm 4.8 \\
(27)\end{array}$ \\
\hline
\end{tabular}

(i) Mean insulin secretion ( $\mu \mathrm{U} / \mathrm{mg}$ per $60 \mathrm{~min} \pm \mathrm{SEM}$ ) by tissue incubated in media containing glucose alone; number of observations shown in parentheses.

(ii) Effects of hormones (concentrations shown in parentheses) are shown as mean changes in insulin secretion rates $(\mu \mathrm{U} / \mathrm{mg}$ per $60 \mathrm{~min} \pm \mathrm{SEM})$ with their statistical significances $\left({ }^{*} P<0.005\right)$; the number of observations is in parentheses.

(iii) Kallikrein inhibitor $(625 \mathrm{KIU} / \mathrm{ml})$ was present in all media.

by propanolol of theophylline-induced secretion (Table I, line 15). However, doubling the concentration ( 2.0 mmoles/liter) of the $\beta$-adrenergic blocking agents (Table IIB, lines 10 and 12 ) resulted in slight enhancement of the effect of glucagon. The hypothesis that glucagon directly activates a $\beta$-receptor may therefore be excluded.

Effects of corticotropin, thyrotropin, oxytocin, and pitressin. Corticotropin and thyrotropin slightly but significantly increased the stimulatory effect of glucose in high concentration $(300 \mathrm{mg} /$ $100 \mathrm{ml}$; Table III, lines 2 and 3), but were ineffective at lower glucose concentrations (100 and $150 \mathrm{mg} / 100 \mathrm{ml}$ ). Oxytocin and pitressin had no significant effect at any glucose concentration (Table III, lines 4 and 5).
Interrelationship between theophylline and glucose metabolism. The lack of stimulant effect produced by these various hormonal and pharmacological agents in the absence of glucose was not due to any lack of tissue viability. Thus, after pieces of pancreas had been incubated for $60 \mathrm{~min}$ in the absence of glucose, they secreted as much insulin (34.9 $\pm 4.2 \mu \mathrm{U} / \mathrm{mg}$ per $60 \mathrm{~min} ; n=9$ ) during a second period of incubation of $60 \mathrm{~min}$ in the presence of glucose $(200 \mathrm{mg} / 100 \mathrm{ml})$ as control tissue incubated with glucose for the first 60 $\min (35.6 \pm 2.8 \mu \mathrm{U} / \mathrm{mg}$ per $60 \mathrm{~min})$.

Insulin secretion by pancreatic tissue incubated in the absence of glucose was observed when the tissue was obtained from rats perfused with glucose for 8-10 hr before death (see Methods). At

TABLE IV

Changes in insulin secretion produced by theophylline $(1.4$ mmoles/liter) and glucagon $(5 \mu \mathrm{g} / \mathrm{ml})$ in media containing no glucose

\begin{tabular}{|c|c|c|c|c|c|}
\hline $\begin{array}{l}\text { Line } \\
\text { No. }\end{array}$ & $\begin{array}{l}\text { Pretreatment } \\
\text { in vivo }\end{array}$ & $\begin{array}{l}\text { Preincubation } \\
\text { in vitro }\end{array}$ & Control* & Theophyllinet & Glucagon $\ddagger$ \\
\hline 1 & $\begin{array}{l}\text { Glucose infusion } \\
(10 \mathrm{hr})\end{array}$ & $\begin{array}{l}\text { Glucose }(300 \mathrm{mg} / 100 \mathrm{ml}) \\
0-4^{\circ} \mathrm{C}, 10 \mathrm{~min}\end{array}$ & $\begin{array}{r}14.7 \pm 2.7 \\
(9)\end{array}$ & $+29.1 \pm 3.6 \S$ & \\
\hline 2 & $\begin{array}{l}\text { Glucose infusion } \\
(10 \mathrm{hr})\end{array}$ & $\begin{array}{l}\text { No glucose } \\
0-4^{\circ} \mathrm{C}, 10 \mathrm{~min}\end{array}$ & $\begin{array}{c}15.7 \pm 1.6 \\
\cdot(12)\end{array}$ & $+23.1 \pm 2.98$ & $+9.1 \pm 2.8 \S$ \\
\hline 3 & Nil & $\begin{array}{l}\text { Glucose }(300 \mathrm{mg} / 100 \mathrm{ml}) \\
37^{\circ} \mathrm{C}, 30 \mathrm{~min}\end{array}$ & $7.9 \pm 0.5$ & $+0.7 \pm 0.9$ & \\
\hline
\end{tabular}

* Mean insulin secretion ( $\mu \mathrm{U} / \mathrm{mg}$ per $60 \mathrm{~min} \pm \mathrm{SEM}$ ) by tissue incubated in the absence of any drug; number of observations shown in parentheses.

$\ddagger$ Effects of drugs are shown as mean changes in insulin secretion rates $(+\mu \mathrm{U} / \mathrm{mg}$ per 60 min $\pm \mathrm{SEM})$ with their statistical significances $(\S P<0.005)$; the number of observations is in parentheses. 


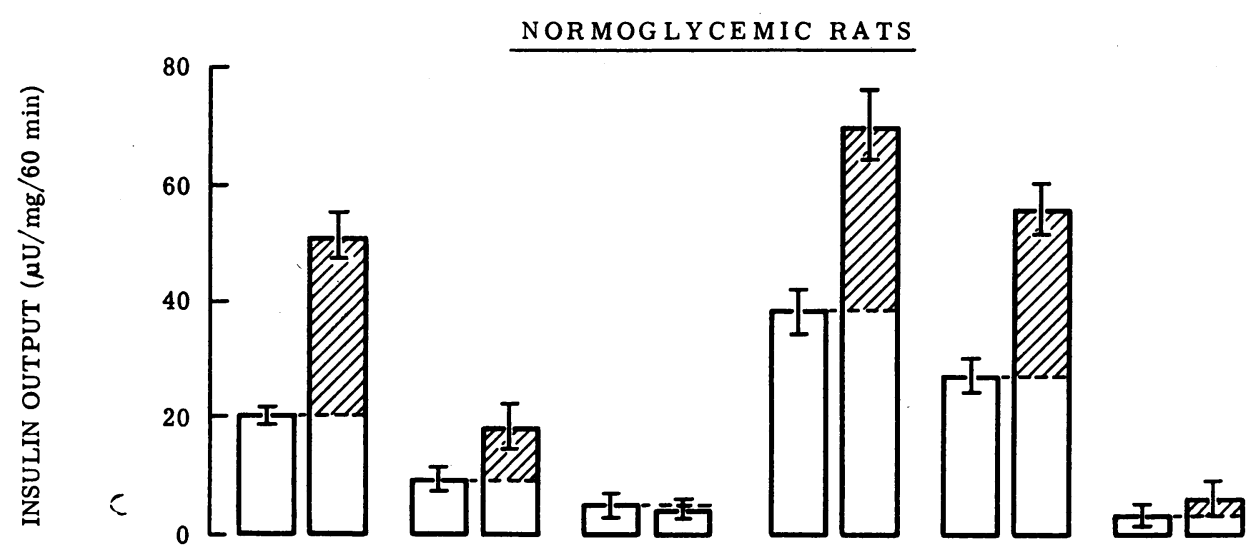

\begin{tabular}{|c|c|c|c|c|c|c|}
\hline $\begin{array}{c}\text { GLUCOSE } \\
(\mathrm{mg} / 100 \mathrm{ml})\end{array}$ & 150 & 150 & 150 & 300 & 300 & 300 \\
\hline $\begin{array}{c}\text { 2-DEOXYGLUCOSE } \\
(\mathrm{mg} / 100 \mathrm{ml})\end{array}$ & - & 150 & - & - & 300 & 1330 \\
\hline MANNOHE PTULOSE & - & - & + & - & - & - \\
\hline
\end{tabular}

Fig. 2. EFFECT OF 2-DEOXYGLUCOSE AND MANNOHEPTULOSE ON INSULIN SECRETION INDUCED BY GLUCOSE AND THEOPHYLLINE. The columns represent mean secretion rates ( \pm SEM) of 18 observations, in the absence (left column) or presence (right column) of theophylline (1.4 mmoles/liter), the shaded area corresponding to the increase in secretion induced by theophylline.

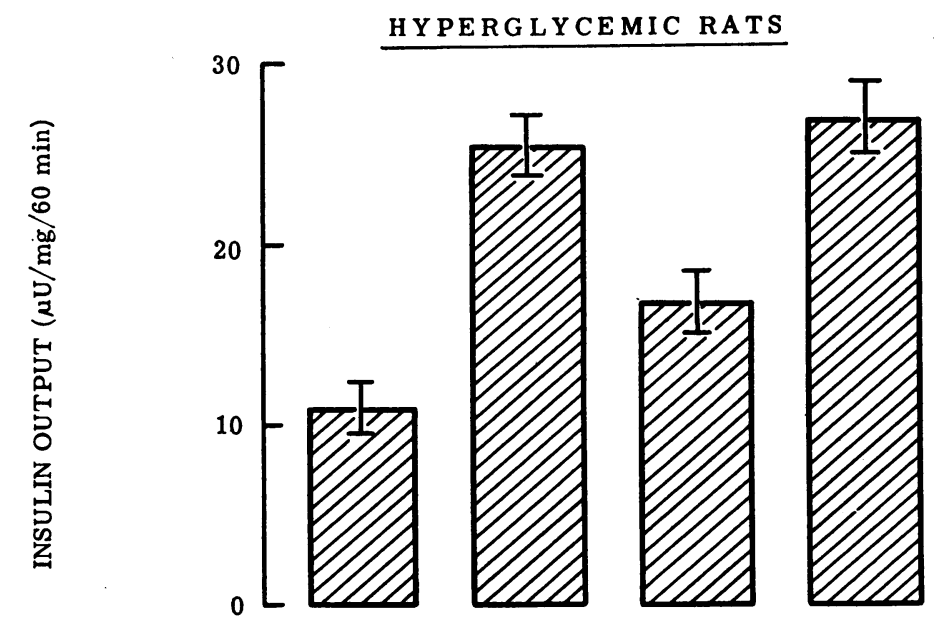

\begin{tabular}{|c|c|c|c|c|}
\hline THEOPHYLLINE & & + & + & + \\
\hline 2-DEOXYGLUCOSE & & & + & \\
\hline MANNOHE PTULOSE & & & & + \\
\hline
\end{tabular}

FIG. 3. EFFECT OF THEOPHYLLINE (1.4 MMOLES/LITER), 2-DEOXYGLUCOSE ( 300 MG/100 ML) AND MANNOHEPTULOSE (SEE METHODS) ON INSUlin SECRETION FROM PIECES OF PANCREAS REMOVED FROM HYPERGLYCEMIC RATS AND INCUBATED IN THE ABSENCE OF GLUCOSE. Preincubation conditions are those described in Table IV, line 2. The columns represent mean secretion rates ( \pm SEM) of 27 observations. 
death, these animals were markedly hyperglycemic (mean plasma-sugar concentration $=1300 \mathrm{mg} /$ $100 \mathrm{ml}$ ) and fine particles of glycogen were histologically demonstrable in their Islets (Best's Carmin). When pancreatic tissue from these animals was incubated in the absence of glucose, both glucagon and theophylline were able to stimulate insulin secretion (Table IV, lines 1 and 2). These stimulant effects were not due to contamination of the incubation medium with glucose, for at the end of the incubation none (less than $5 \mathrm{mg} / 100$ $\mathrm{ml}$ ) could be detected; and the same phenomenon was observed with tissue dissected and washed in glucose-free buffer for about $10 \mathrm{~min}$ before incubation (Table IV, line 2). No such effect was observed when tissue from normoglycemic rats was preincubated for $30 \mathrm{~min}$ at $36^{\circ} \mathrm{C}$ in a medium containing glucose in high concentration $(300 \mathrm{mg} / 100$ $\mathrm{ml}$ ) and then incubated with theophylline in the absence of glucose (Table IV, line 3). These results suggested that theophylline can only exert its effect when there is either an extra- or intracellular source of glucose.

This hypothesis was confirmed by incubating tissue from normoglycemic and hyperglycemic rats with mannoheptulose and 2-deoxyglucose (Figs. 2 and 3). Insulin secretion by tissue from the normoglycemic rat is completely inhibited by mannoheptulose when glucose $(150 \mathrm{mg} / 100 \mathrm{ml})$ is present in the medium either alone or with theophylline (Fig. 2). When glucose and 2-deoxyglucose are present in equal low concentrations $(150 \mathrm{mg} / 100 \mathrm{ml})$, the stimulant effects of glucose and theophylline are reduced $(P<0.05)$. If the glucose concentration is raised to $300 \mathrm{mg} / 100$ $\mathrm{ml}$, all stimulation of insulin secretion can be abolished by addition of a high concentration of 2-deoxyglucose $(1330 \mathrm{mg} / 100 \mathrm{ml})$. These results, summarized in Fig. 2, differ from those obtained with tissue from the hyperglycemic rats and illustrated in Fig. 3. In this case and in the complete absence of glucose from the incubation medium, secretion induced by theophylline was markedly inhibited $(P<0.005)$ by a moderate concentration of 2 -deoxyglucose $(300 \mathrm{mg} / 100 \mathrm{ml})$ but was unaffected by mannoheptulose.

\section{Discussion}

The present experiments show that isoproterenol, a predominantly $\beta$-adrenergic agent, slightly stimulates insulin secretion in the presence of an $\alpha$-adrenergic blocking agent. A comparable stimulant effect was obtained with $3^{\prime} 5^{\prime}$-cyclic AMP and this effect was mimicked by theophylline which, like caffeine, is known to inhibit phosphodiesterase and the destruction of $3^{\prime} 5^{\prime}$-cyclic AMP (15). No inhibition of the effect of theophylline could be induced here with nicotinic acid, but it should be pointed out that the activation of the phosphodiesterase by nicotinic acid is not firmly established (16) and that the concentrations used here might have been optimal to detect a competitive antagonism between theophylline and nicotinic acid. These observations indicate, as suggested recently (5, $17,18)$, that the $\beta$-cells may be equipped with an adenylcyclase system comparable to those existing in liver and adipose tissue and that activation of this system results in insulin secretion. In none of these experiments summarized in Table I was a stimulant effect obtained in the absence of glucose, the effect being most apparent when glucose was present in concentrations above about $100 \mathrm{mg} /$ $100 \mathrm{ml}$.

A similar close relationship between stimulation of insulin secretion and the concentration of glucose in the incubation medium was found with glucagon, corticotropin, and thyrotropin, all of which are known to activate adenylcyclase in the liver (19) or in adipose tissue (8). The stimulant effect of glucagon has been demonstrated both in vivo $(4,20,21)$ and in vitro (22-24) but, if anything, it is weaker than that of theophylline as it only becomes apparent at concentrations of glucose above $150 \mathrm{mg} / 100 \mathrm{ml}$ (Table II). The effects or corticotropin and of thyrotropin are even less pronouced as they were only obtained with high concentrations of glucose (Table III; 300 $\mathrm{mg} / 100 \mathrm{ml}$ ). Oxytocin and pitressin, which neither activate adenylcyclase nor promote lipolysis in adipose tissue of the rat (25), were ineffective (Table III) even at the highest concentration of glucose. Though the observed effects of these hormones are similar to that of the $\beta$-adrenergic agent used here (isoproterenol), that of glucagon, for example, was not abolished by $\beta$-blocking agents (Table II; propanolol and nethalide) known to suppress the stimulant effect of isoproterenol (5). This suggests that the stimulant effect of these hormones is due to a direct activation of adenylcyclase and does not involve any 
$\beta$-adrenergic receptor site; their action in the $\beta$-cell is thus comparable with that observed in adipose tissue (26).

The present observations are largely in agreement with preliminary data, published elsewhere. Thus, Porte (17) found a small increase in the level of circulating insulin in human subjects infused with isoproterenol. In addition to the numerous reports of the stimulant effect of glucagon in vivo $(4,20,21)$ and in vitro (22-24), Sussman, Vaughn, and Timmer (18) have shown that $3^{\prime} 5^{\prime}$ cyclic AMP and corticotropin stimulate insulin secretion in the perfused rat's pancreas. On the other hand, Balasse and coworkers $(27,28)$ obtained no increase in the level of circulating insulin in dogs perfused with lysine-8-vasopressin and only a transient initial rise in dogs perfused with oxytocin. The results obtained here cannot be compared in any quantitative manner with the results of experiments carried out in vivo but should be considered in the light of reports of those carried out in vitro. Grodsky and Bennett (22), for example, stimulated insulin release in the perfused rat's pancreas by injecting a "pulse" of perfusion medium containing glucagon but no glucose; increased secretion was observed within 30 sec. In the complete absence of glucose and with nothing in the medium to counteract the effects of lytic substances released from incubated pieces of the rat's pancreas, Devrim and Recant (23) were also able to stimulate insulin secretion with glucagon. Even in the presence of glucose (60 and $300 \mathrm{mg} / 100 \mathrm{ml}$ ), Coore and Randle (1) failed to stimulate insulin secretion with glucagon in pieces of the rabbit's pancreas. By a similar method Turner and McIntyre (24) succeeded and suggested that the rabbit's Islets are more sensitive to glucagon when the incubation medium contains high $(300 \mathrm{mg} / 100 \mathrm{ml})$ rather than low $(60 \mathrm{mg} /$ $100 \mathrm{ml}$ ) concentrations of glucose. Whatever the reasons for these discrepancies, the present results consistently and clearly show that stimulation of insulin secretion by glucagon, corticotropin, thyrotropin, caffeine, theophylline, and $3^{\prime} 5^{\prime}$-cyclic AMP is closely related to and dependent upon the metabolism of glucose. In the cases of the protein hormones, too much attention to their quantitative effects is not warranted since the kallikrein inhibitor (Trasylol) used to prevent their destruction was probably only partly effective; it reduced but it did not abolish destruction of insulin in the absence of anti-insulin serum (Fig. 1). The effects produced by the polypeptide hormones used here could well be less than those which should be attributed to the concentrations of the hormones added to the media.

A possible relationship between the stimulant effects of these substances and the metabolism of glucose is suggested by comparison of the results obtained with pancreatic tissue from normoglycemic and hyperglycemic rats. The only source of glucose available to the pancreatic tissue of the normoglycemic rat is the incubation medium for, as Lazarow has shown (29), the $\beta$-cells of the normal rat's pancreas contain no detectable glycogen. In this tissue, mannoheptulose, which inhibits phosphorylation of glucose (30), abolishes the stimulant effects of both glucose and theophylline upon insulin secretion (Fig. 2). A similar inhibitory effect is produced by addition to the medium of 2-deoxyglucose which competitively inhibits the isomerization of glucose-6-phosphate to fructose6-phosphate (31). To induce stimulation of insulin secretion with theophylline, therefore, glucose must not only be phosphorylated but must also be metabolized to fructose-6-phosphate and beyond. An alternative source of glucose-6-phosphate was obtained when rats were killed after infusion with glucose for 8-10 hr. Under these conditions, glycogen was seen to accumulate in the $\beta$-cells; it was demonstrated histologically but was not estimated chemically. Pieces of pancreas obtained from these animals, even in the absence of glucose from the medium, secreted more insulin in the presence of theophylline and glucagon than in their absence (Table IV). The stimulant effect of theophylline was also reduced by addition to the medium of 2-deoxyglucose but was unaffected by mannoheptulose (Fig. 3).

These results are compatible with the following working hypotheses. First, and as others have suggested previously $(1,6)$, insulin secretion normally occurs at a rate which may be governed by the rate at which glucose-6-phosphate is metabolized through the glycolytic pathway. The factors which control onset of secretion at low glucose concentrations and the maximum rate achieved at high concentrations remain to be determined. Secondly, those substances which stimulate formation of $3^{\prime} 5^{\prime}$-cyclic AMP - (glucagon, 


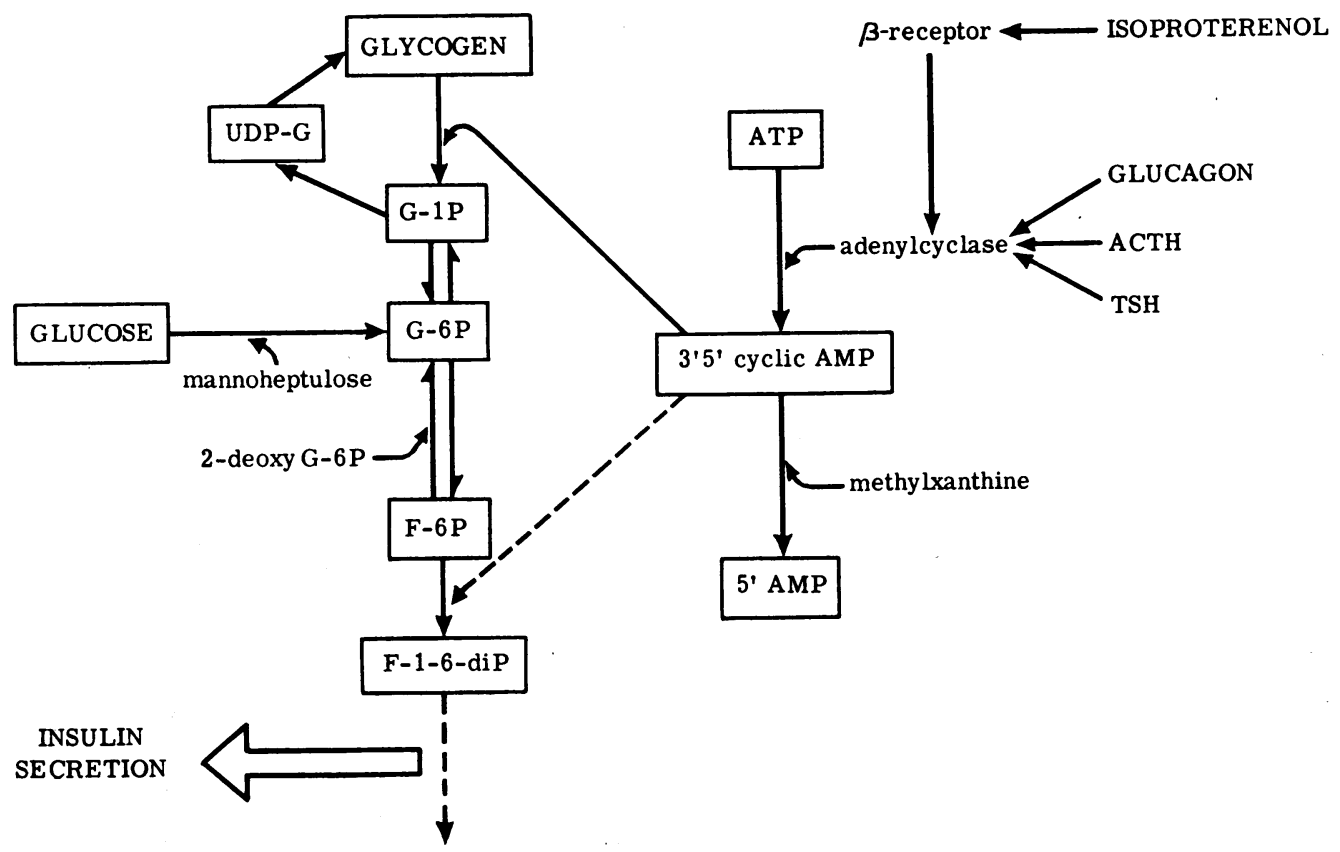

Fig. 4. POSSIBLE SITES OF ACTION OF DRUGS AND HORMONES AFFECTING INSULIN SECRETION IN VITRO.

corticotropin, and thyrotropin) or inhibit its breakdown (theophylline, caffeine, etc.) in the liver or adipose tissue, might well have a similar action in the pancreatic $\beta$-cell. One way in which they could stimulate insulin secretion would be by inducing activation of phosphorylase and so increasing glycogenolysis and the size of the pool of intracellular glucose-6-phosphate (Fig. 4). This would explain the effect of theophylline upon secretion by tissue obtained from the hyperglycemic rats, its inhibition by 2-deoxyglucose, and the lack of effect of mannoheptulose. If glycogen is formed at an appreciable rate during incubation of normal pancreatic tissue in media containing high concentrations of glucose, this unitary hypothesis could also explain why theophylline augments the maximum effect which can be induced by glucose alone and why its action can be completely inhibited by 2-deoxyglucose. It is also possible, however, that $3^{\prime} 5^{\prime}$-cyclic AMP and related stimulants could accelerate rate-limiting reactions in the glycolytic pathway or in the tricarboxylic acid cycle; the phosphorylation of fructose-6-phosphate is a possible site (32). With the advent of simpler methods for the isolation of individual Islets (12, 33 ), these possibilities should now become amenable to investigation. In the meantime, the present results strongly suggest that, if not essential for the stimulation of insulin secretion, those hormones or drugs which influence the adenylcyclase system can augment the action of glucose, the physiological stimulant for insulin secretion.

\section{Acknowledgments}

We wish to thank all those who kindly supplied samples of drugs and hormones; Doctors J. Ashmore and P. H. Wright for their encouragement and advice, and Miss Susanne King for skilled technical assistance.

\section{References}

1. Coore, H. G., and P. J. Randle. 1964. Regulation of insulin secretion studied with pieces of rabbit pancreas incubated in vitro. Biochem. J. $93: 66$.

2. Kris, A. O., R. E. Miller, F. E. Wherry, and J. W. Mason. 1966. Inhibition of insulin secretion by infused epinephrine in Rhesus monkeys. Endocrinology. $78: 87$.

3. Porte, D., Jr. A. L. Graber, T. Kuzuya, and R. H. Williams. 1966. The effect of epinephrine on immunoreactive insulin levels in man. J. Clin. Invest. $45: 228$.

4. Karam, J. H., S. G. Grasso, L. C. Wegienka, G. M. Grodsky, and P. H. Forsham. 1966. Effect of selected hexoses of epinephrine and of glucagon on insulin secretion in man. Diabetes. 15: 571.

5. Malaisee, W., F. Malaisse-Lagae, P. H. Wright, and J. Ashmore. 1967. Effects of adrenergic and cholinergic agents upon insulin secretion in vitro. Endocrinology. 80: 975. 
6. Malaisse, W., F. Malaisse-Lagae, and P. H. Wright. 1967. A new method for the measurement in vitro of pancreatic insulin secretion. Endocrinology. 80 : 99.

7. Sutherland, E. W., and T. W. Rall. 1960. The relation of adenosine- $3^{\prime} 5^{\prime}$-phosphate and phosphorylase to the actions of catecholamines and other hormones. Pharmacol. Rev. 12: 265.

8. Butcher, R. W. 1966. Cyclic 3'5'-AMP and the lipolytic effects of hormones on adipose tissue. Pharmacol. Rev. 18: 237.

9. Wright, P. H., and L. L. Norman. 1966. Some factors affecting insulin antibody production in guinea pigs. Diabetes. 15 : 668.

10. Wright, P. H., W. Malaisse, and I. J. Reynolds. 1967. The assay of partially neutralized guinea-pig anti-insulin serum. Endocrinology. $81: 226$.

11. Richtmyer, N. K. 1962. D-Manno-heptulose isolation from the Avacado. In Methods in Carbohydrate Chemistry. R. L. Whistler and M. L. Wolfrom, editors. Academic Press, Inc., N. Y. 1: 173.

12. Malaisse, W. J., F. Malaisse-Lagae, P. E. Lacy, and P. H. Wright. 1967. Insulin secretion by isolated islets in the presence of glucose, insulin and antiinsulin serum. Proc. Soc. Exptl. Biol. Med. 124: 497.

13. Wright, P. H., and W. J. Malaisse. 1966. A simple method for the assay of guinea pig anti-insulin serum. Diabetologia. 2: 178.

14. Ahlquist, R. P. 1948. A study of the adrenotropic receptors. Am. J. Physiol. 153: 586.

15. Butcher, R. W., and E. W. Sutherland. 1962. Adenosine $3^{\prime}, 5^{\prime}$-phosphate in biological materials. 1. Purifications and properties of cyclic $3^{\prime}, 5^{\prime}$-nucleotide phosphodiesterase and use of this enzyme to characterize adenosine $3^{\prime}, 5^{\prime}$-phosphate in human urine. J. Biol. Chem. $237: 1244$.

16. Krishna, G., B. Weiss, J. I. Davies, and S. Hynie. 1966. Mechanism of nicotinic acid inhibition of hormone-induced lipolysis. Federation Proc. 25 : 719. (Abstr.)

17. Porte, D., Jr. 1966. Stimulation of insulin release by a beta-adrenergic receptor. Diabetes. $15: 543$. (Abstr).

18. Sussman, K. E., G. D. Vaughn, and R. F. Timmer. 1966. Factors controlling insulin secretion from the perfused isolated rat pancreas. Diabetes. 15 : 521. (Abstr.)
19. Sutherland, E. W., and G. A. Robison. 1966. The role of cyclic-3',5'-AMP in responses to catecholamines and other hormones. Pharmacol. Rev. 18 : 145.

20. Samols, E., G. Marri, and V. Marks. 1965. Promotion of insulin secretion by glucagon. Lancet. 2 : 415.

21. Crockford, P. M., D. Porte, Jr., F. C. Wood, Jr., and R. H. Williams. 1966. Effect of glucagon on serum insulin, plasma glucose and free fatty acids in man. Metabolism. 15: 114.

22. Grodsky, G. M., and L. L. Bennett. 1966. Time sequence in the release of insulin: The effect of glucose, glucagon and potassium. Diabetes. 15: 521. (Abstr.)

23. Devrim, S., and L. Recant. 1966. Effect of glucagon on insulin release in vitro. Lancet. $2: 1227$.

24. Turner, D. S., and N. McIntyre. 1966. Stimulation by glucagon of insulin release from rabbit pancreas in vitro. Lancet. $1: 351$.

25. Rudman, D. 1963. The adipokinetic action of polypeptide and amine hormones upon the adipose tissue of various animal species. J. Lipid Res. $4: 119$.

26. Wenke, M., J. Cepelik, M. Cernohorsky, and D. Lincova. 1966. Adrenergic receptors for lipid mobilization and tracheal relaxation. The Pharmacologist. 8: 195.

27. Balasse, E., and E. Rasio. 1965. Mecanisme d'action de l'ocytocine sur la concentration plasmatique des acides gras libres (A.G.L.) chez le chien. Arch. Intern. Pharmacodyn. 157 : 356.

28. Balasse, E., E. Rasio, and V. Conard. 1966. Action insulino-mimetique de la vasopressine chez le chien. Arch. Intern. Pharmacodyn. 161 : 392.

29. Lazarow, A. 1963. Functional characterization and metabolic pathways of the pancreatic islet tissue. Recent Progr. Hormone Res. 19 : 489.

30. Coore, H. G., and P. J. Randle. 1964. Inhibition of glucose phosphorylation by mannoheptulose. Biochem. J. $91: 56$.

31. Wick, A. N., D. R. Drury, H. I. Nakada, and J. B. Wolfe. 1957. Localization of the primary metabolic block produced by 2-deoxyglucose. J. Biol. Chem. 224 : 963.

32. Mansour, T. E. 1966. Factors influencing activation of phosphofructokinase. Pharmacol. Rev. 18: 173.

33. Lacy, P. E., and M. Kostianovsky. 1967. Method for the isolation of intact islets of Langerhans from the rat pancreas. Diabetes. $16: 35$. 